\title{
COMMERCIAL BANKING AND PERSONAL INDEBTEDNESS IN CROATIA ${ }^{* * * *}$
}

Social phenomenon of personal over-indebtedness has emerged in the past thirty years. The trend of excessive indebtedness of households is not losing but gaining momentum. The problem of personal over-indebtedness becomes the focus of interest of regulators, research community and the public in general. In Croatia the number of citizens whose bank accounts are frozen as well as the level of their debt is steadily rising. One of the reasons of such trend is easier access to debt. Studies document the process of 'credit democratization', one of the reasons enabling it being the relaxation of financial regulation. Only few studies can be found that research the role of bank operations policies in inducing the higher levels of household debt. Bank marketing, specifically the advertising and promotion are the tools to communicate with clients, and it has been proven that effective marketing content is as powerful as the interest rate level in deciding upon getting a credit. This leads the way to the research of possible relation between marketing efforts of the bank and the level of household indebtedness.

This paper focuses on the possible proactive role of banks, driven by the profitability, and accompanied with the inappropriate quality and level of regulation, in the rise of the number of over-indebted persons in Croatia. The effect of the economic downturn on the proposed relationship is also taken into account. The analysis is based on the bank financial statements data and selected macroeconomic indicators. The goal of the paper is to describe how banks impact the consumer behavior, and consequently give incentive to the rise of personal indebtedness in Croatia.

Keywords: Commercial Banking, Consumer Behavior, Croatia, Personal Overindebtedness

* Ivan Filipović, Primorje-Gorski Kotar County, Croatia, ivan.filipovic7@gmail.com

** Associate Professor Dunja Škalamera-Alilović, $\mathrm{PhD}$

Faculty of Economics, University of Rijeka, Croatia, dunja.skalamera-alilovic@efri.hr

*** Assistant Professor Ana Štambuk, PhD

Faculty of Economics, University of Rijeka, Croatia, ana.stambuk@efri.hr

**** This work has been supported by the Croatian Science Foundation under the project 6558 Business and Personal Insolvency: The Ways to Overcome Excessive Indebtedness. 


\section{Introduction}

Banks as financial institutions that ensure capital resources to businesses and households are continuously involved not only in business but also in everyday life of a society. Households currently represent the most interesting target group for banks that is ready to spend a part of their income on acquisition of bank services.

With the use of the synergy of its different business functions, the primary goal of the bank, like any other business, is to maximize profits. Today, in modern and changeable business environment, that goal is somewhat disguised with the purpose of putting upfront banks' role in boosting economic growth and prosperity in an economy. Thus, consumers, influenced by their preferences on the one side, and by different factors from the environment on the other, are often being encouraged through various bank activities, including marketing, to regard bank services as means to their economic advancement, with no reflection on banks profit motivation. Household trends in bank business in terms of deposits, loans and purchasing power in Croatia had not significantly changed until 2008, when the global economy was affected by the financial crisis. The fact is, until then the purchasing power had kept growing steadily. Not taking into account the macroeconomic aspect and further government borrowing, the household sector maintained the upward trend of consumption from year to year, and that resulted in the growth of the total debt in the banking system. Individuals, families or society as whole, maintained adequate lifestyle covered not only by current income, but also by getting into debt in order to improve the social and economic status. Research labeled over-indebtedness as a significant social and economic issue. ${ }^{1}$ A person or a household is considered to be over-indebted if it falls behind with their payments on the structural basis or is in an immediate greater danger to be found in such a state. Such issue disproportionately affects lower income groups (especially where there is no significant modification of financial resources/income) during the time of neoliberalism and deregulation. The ideology of neo-liberalism is associated with privatization, regulation downsizing and reduction of government costs.

The whole financial system of institutions, the banks being the most prominent ones among them, is interconnected and involved in the creation of the credit market supply. Contemporary business environment in which banks operate is characterized by the increased competitiveness, deregulation of markets, increased transparency of operation and despecialization of business. Following deregulation, not only the overall lending increased, but bankruptcy rates rose as well. ${ }^{2}$ Besides banking deregulation, the relaxation of bank entry restric-

Ramsay, I. (2012): “A Tale of Two Debtors: Responding to the Shock of Over-Indebtedness in France and England - A Story from the Trente Piteuses”, Modern Law Review, 75(2), 212-248.

2 Dick, A. A., Lehnert, A. (2010): "Personal Bankruptcy and Credit Market Competition", The Journal of Finance, 65(2), 655-686. 
tions in the 1980s and 1990s with technological change in consumer lending increased credit market competition and therefore affected the supply of credits. New technologies change the way loans are made, allowing for interest rates to better reflect underlying risk and, thus, facilitating lending to riskier borrowers. Furthermore, Dick and Lehnert indicate that increased competition prompted banks to adopt sophisticated credit rating technology, allowing for new credit extension to existing and previously excluded households. ${ }^{3}$ Another research results support the thesis that deregulation increases the rate of business incorporations, thus suggesting an increase in credit availability for the sector. ${ }^{4}$ Both lead to the increase in credit and economic growth.

Banks continue to adapt their business to the changing and specific circumstances on the market, as well as to the legislative, financial and economic pressures from the environment. Besides, banks try to develop suitable strategies in a timely manner and manage change in order to achieve sustainable growth and profitability, regardless of the outcomes on the level of their clients, notably the households. However, when it comes to the growing trend of personal over-indebtedness management encouraged by irresponsible credit granting, the responsibility of the regulator needs to be highlighted in the banking sector. Van Heerden and Renke point out that in the context of the prevention of over-indebtedness, responsible lending practices by credit providers play a pivotal role in avoiding consumers getting caught in a debt trap, which leaves them locked into a vicious cycle of overindebtedness. ${ }^{5}$ It is thus of importance for a country and government to ensure that the financial welfare of its consumers maintains on the healthy credit market with an effective responsible lending regime. That way irresponsible credit granting may be avoided and debt relief to over-indebted consumers can be provided.

In this paper the causes, effects and implications of the growth of personal indebtedness and household credit availability are examined. The case of Croatia is presented through the display of lending trends in the last decade, including the years of global financial crisis. Special attention is given to the analysis of the possible active role which bank marketing could have in contributing to the ever rising trend of personal over-indebtedness. Finally, conclusions are given with the proposal for the future research of the impact that banks have on the issue of excessive personal debt.

\section{Ibid.}

Black, S. E. and Strahan, P.E. (2002): "Entrepreneurship and Bank Credit Availability", The Journal of Finance, 57(6), 2807-2833.

$5 \quad$ Van Heerden, C. and Renke, S. (2015): "Perspectives on the South African Responsible Lending Regime and the Duty to Conduct Pre-agreement Assessment as a Responsible Lending Practice", International Insolvency Review, 24(2), 67-95. 


\section{Household credit availability and the growth of personal debt}

The last two decades of the 20th century witnessed a dramatic increase in personal bankruptcy filings which continued into the new millennium. In particular, in the USA, the personal bankruptcy rate has increased more than threefold in the last two decades of the last millennium. Livshits argues that households can quite effectively smooth transitory income shock over time, as long as they are able to borrow (sufficient a mounts and at good interest rate). ${ }^{6}$ The aspiration for higher living standard or at least the maintenance of the already reached standard pushes households to make unsound borrowing decisions. They are driven by favorable loan conditions and result in higher levels of indebtedness. Furthermore, such activities contribute to the development and growth of banking industry. For example, the borrowing of middle class increased despite non increased income on the USA market. ${ }^{7}$ In his research Ramsay compares two markets: English and French. ${ }^{8}$ By 2010 the majority of debtors in France had net revenues lower than the minimum wage. Also, a rapid growth of personal bankruptcy files received (for providing a solution to individual's financial situation) is noted. According to the situation in England, the number of consumer credits had doubled since 1980s which caused credit expansion. The majority of English bankruptcies were related to consumer debt rather than the business reasons. Consumer bankruptcies represent in 2010s over 80 per cent of bankruptcies compared with 39 per cent during the height of the early 1990s recession. ${ }^{9}$ The increased numbers of consumer insolvencies may also lead to the question if neoliberal ideas and commitment to a 'competitive social market economy', which European Union advocates, contributes to the growth of over-indebtedness. ${ }^{10}$ Ramsay concludes that the law of over-indebtedness may symbolize the breakdown of social and family sources of solidarity and the rise in inequality associated with neoliberalism. ${ }^{11}$

The presence of uncertainty on the market led to insolvency, lowered the value of real estate and had other negative effects on the overall economy. Changes on the market caused financial crisis, which initially started in the United States. The business of European and other global banks on the US market were affected by the same consequences which enabled spreading of the crisis not only to Europe but also globally.

6 Livshits, I. (2015): "Recent Developments in Consumer Credit and Default Literature", Journal of Economic Surveys, 29(4), 596, 597.

7 Attali, J. (2009): Kriza, a poslije?, Meandar Media, Zagreb.

8 Ramsay, I. (2012)

$9 \quad$ Ibid, 237.

$10 \quad$ European Commission (2008): Towards a Common Operational European Definition of Over-Indebtedness, DG Employment, Social Affairs and Equal Opportunities, Brussels.

11 Ramsay, I. (2012), 247. 
However the rise in consumer bankruptcies is not primarily driven by the increase in uncertainty, but rather by changes in the consumer credit market. The information-related mechanisms which include improvements in information technology (IT) (improved availability, accuracy and timeliness of information, lower lending and credit processing costs, lower costs of identifying and targeting pools of borrowers based on their (risk) characteristics and related combinations) lead to the rise in bankruptcy rates. The causes are twofold: intensive margin of existing borrowers and extensive margin of new borrowers gaining access to credit. The latter phenomenon is labeled as "democratization of credit" and it came from lenders. ${ }^{12}$ It may be also connected with information content marketing and rising marketing activities of the banks to promote and encourage borrowers to use their services.

After the occurrence of uncertainty on the market, the overall debt has risen as well as personal debt per capita. This trend has particularly been influenced by demographic trends of ever larger proportion of older people who try to maintain the achieved living standard through debt, and by changing sets of values that favor consumerism inducing higher levels of consumption across all age groups. Banks encourage such behaviors by selective information practices towards their clients, which in turn have a notable impact on the growing problem of household indebtedness.

\subsection{Consumer behavior and commercial banking}

In the past little attention was paid to social and psychological aspects of debt. People attributed their debt problems to their pleasure in consumption (greed and enjoyment in shopping). Kahneman and Tversky explained the new progress of cognitive psychology according to which people in similar circumstances would rather choose the perceived gain than the perceived loss. ${ }^{13}$ However, the rise of personal debt is causing problems for banks and other lending institutions as well as for private individuals. ${ }^{14}$

The banks define marketing strategies which will not only attract potential, but also retain existing customers. The digitalization of financial services and the way in which banks adapt their services to the clients' needs (with the help of aggressive advertising and promotion) contribute to the creation of profit and attraction of new bank clients. ${ }^{15}$ Successful promotional activities of a bank and

12 Livshits, I. (2015), 599.

13 Kahneman, D. and Tversky, A. (2000): Choices, Values and Frames, Cambridge University Press, Cambridge.

14 Leigh-Pemberton, R. (1989): "Personal credit problems", Bank of England Quarterly Bulletin, 29(May), 243-245.

15 Westerman, G. et. al. (2012): The Digital Advantage: How digital leaders outperform their peers in every industry (Working paper), MA: MIT Sloan Management, Cambridge.

Vol. 14, № 1, 2017: 187-206 
availability of credit cards can encourage consumers to often use credit cards, increase the demand for bank services and consequently increase personal indebtedness. ${ }^{16}$ Additionally, the bank marketing may increase the profitability of the bank; thus with the proper decisions of the bank management and necessary promotional activities, negative effects from the environment, such as financial crisis, can be bypassed. ${ }^{17}$

The next issue that relates to the uneven exposure of consumers to financial information has to do with extraordinary gap between the levels of investment into financial education versus financial industry marketing. In the United States about 25 times more is spent on financial industry marketing efforts than on financial education. ${ }^{18}$ Approximately 670 million dollars are spent annually on providing financial education by government and others. At the same time, the financial services industry spends approximately 17 billion dollars annually on marketing consumer financial products and services. Besides, Cameron and Golby noted that if social comparison processes drive people, they consume even more. ${ }^{19}$ Those in more debt are the people who take financial risks based on often unreasonable expectations of the payoff. Also, there is negative correlation between self-control and income. These findings add to the argument that individuals are overwhelmed by bank selected information and that government should play a more proactive role in the prevention of over-indebtedness.

Based on the well-known life cycle hypothesis of saving, consumers attempt to maintain their lifestyle even though their income and wealth may fluctuate over time. ${ }^{20}$ Specifically, older consumers can borrow from their past savings and consume at levels beyond their current incomes. Conversely, young consumers who expect future incomes to be higher than their present income can borrow from their future income to support their present lifestyle. This phenomenon is called intertemporal smoothing. Prior behavioral research confirmed

$16 \quad$ Turan, Ö. et. al. (2013): "Dynamics of Consumerism and Credit Card Debt under the Influence of Advertising", in: 31st International Conference of the System Dynamics Society 2013 Proceedings, 3852-3867. http://www.systemdynamics.org/conferences/2013/proceed/ papers/P1301.pdf (retreived 10.11.2015)

17 Janković, B. (2009): "Bank marketing in times of the global economic crisis - risk and/or chance?", Bankarstvo, 39(9-10), 52-69, http://www.ubs-asb.com/Portals/0/ Casopis/2009/9_10/B09-10-2009-Jankovic.pdf (retrieved 25.09.2015)

18 Consumer Financial Protection Bureau [CFPB] (2013): Navigating the Market: A Comparison of Spending on Financial Education and Financial Marketing, Consumer Financial Protection Bureau, Washington, http://files.consumerfinance.gov/f/201311_ cfpb_navigating-the-market-final.pdf (retrieved 10.03.2016)

19 Cameron, S. and Golby, D. (1990): "Correlates of Over-Commitment in a Sample of Crisis Debtors”, in: S.E.G. Lea, P. Webley and B.M. Young (eds.), Applied economic psychology in the 1990s, 467-475, Exeter: Washington Singer Press.

20 Modigliani, F., Brumberg, R. (1954): "Utility Analysis and the Consumption Function: An Interpretation of Cross-section Data", in: K. K. Kurihara (ed.) Post Keynesian Economics, (388-436), Rutgers University Press, New Brunswick. 
that consumers are unable to correctly value their present and future resources, and they lack the cognitive capability to solve the intertemporal optimization problem required by the life cycle hypothesis. Furthermore, it is argued that consumers use external information such as the availability of credit to infer their future earnings. Consequently, there are negative social, psychological as well as economic implications of such consumer behavior.

\subsection{Credit limit as a factor of indebtedness}

Credit limit perceived as measure of credibility has a moderating role on the level of indebtedness. Specifically, if consumers have easy access to large amounts of credit, and they believe that the credit limit credibly represents their future earnings potential (typical belief of a naive consumer who has limited experience with consumer credit) they are likely to infer that their lifetime income is high and hence their willingness to use credit will also be high. Besides, as a routine practice, credit limit is freely used in banking industry as a tactical marketing tool. Credit limits on most accounts have been steadily ratcheted up ${ }^{21}$, and when credit card users with good payment records reach their limit, their credit line is typically increased ${ }^{22}$. As a result, the presumed rationality of the creditlimit-setting process is called into question. The weight is put on consumer and it is also up to a person how he or she will behave. Finally, when card limits for households are increased, this causes a significant rise in debt. ${ }^{23}$

The increase of credit cards availability over time had an impact on the growth of consumer borrowing and over-indebtedness. Research confirms positive relationship between consumer credit and consumption. ${ }^{24}$ Such positive relationship had been provided by the liberalization policies on the credit market. ${ }^{25}$ Eventually, the increased promotion of credit cards induced greater availability of credit which had considerable impact on growth of the personal indebtedness.

Banking industry deregulation and increased competition in credit markets had an adverse effect on consumer default. ${ }^{26}$ That was reflected in a consumer bankruptcy rate increase. It occurred via two channels: increase in credit and the use of new screening technologies introduced after deregulation which allowed

\footnotetext{
$\overline{21} \quad$ Lunt, P. (1992): "What boosts card usage?", ABA Banking Journal, 84(30), 82-85.

22 Punch, L. (1992): “The latest anti-attrition tool: More credit”, Credit Card Management, 5(5), 48-51.

23 Gross, D.B. and Souleles, N.S. (2002): “An Empirical Analysis of Personal Bankruptcy and Delinquency", Review of Financial Studies, 15(1), 319-347.

24 Ludvigson, S. (1999): "Consumption and Credit: A Model of Time-Varying Liquidity Constraints", The Review of Economics and Statistics, 81(3), 434-447.

25 Bilgin, Z. and Yavas, U. (1995): "Marketing of Consumer Credit Services in a Developing Country - A Status Report”, International Journal of Bank Marketing, 13(5), 311-36.

26 Dick, A. A., Lehnert, A. (2010).
} 
credit to be extended to the new consumers. Although the risk of any given borrower defaulting did not necessarily rise, the presence of many extra borrowers in the population perforce increased the bankruptcy rate. The mentioned happenings led to a type of democratization of credits where they became easily accessible to a large amount of people with both low income and questionable future revenues. According to Leigh-Pemberton, personal debt has risen sharply in the United Kingdom because of the removal of restrictions on consumer borrowing, a greater range of credit sources, and increased amounts loaned in proportion to disposable income or securities. ${ }^{27}$

Walker ${ }^{28}$ and Harper ${ }^{29}$ have articulated that recent practices suggest that personal debt has arisen largely as a result of structural changes in employment, credit and housing markets. It is necessary to understand ideology and the complex social systems so that management, government and its financial framework can 'cure' the problem of cognitive financial delinquency. However, the consumption, as a social dimension, integrates people within the general system of capitalist exploitation and encourages them to realize their 'false' identities, aspirations and interests through a process of ownership of goods. ${ }^{30}$ Also, the consumer culture and attractive offers on the market give consumers the illusion of freedom, choice and satisfaction, in the long term, as the replacement for the actual loss of these qualities.

\section{Personal indebtedness trends in Croatia and financial crisis}

Even though the demand for household loans has been slightly decreasing on the Croatian financial market since 2009, the proportion of bad loans has increased. At the same time government debt has been increasing, and GDP fell precipitously in $2009(-8,9 \%)^{31}$, interest rates increased, the share of non-performing loans of the households increased by $25 \%$ and industrial production fell by $16 \% .^{32}$ The changing structure of the loan allocation by banks in Croatia in the last twenty years can be discerned from the data presented in Table 1.

$27 \quad$ Leigh-Pemberton, R. (1989).

28 Walker, C. (2012): "Personal Debt, Cognitive Delinquency and Techniques of Governmentality: Neoliberal Constructions of Financial Inadequacy in the UK", Journal of Community \& Applied Social Psychology, 22(6), 533-538.

29 Harper, D. J. (2003): "Poverty and Discourse", in: S.C. Carr and T.S. Sloan (Eds.) Poverty and Psychology: From Global Perspective to Local Practice, (185-203), Springer, New York.

30 Burić, I. (2010): Nacija zaduženih, Zagreb: Naklada Jesenski i Turk, Hrvatsko sociološko društvo.

31 Bokan, N. et. al. (2010): “Utjecaj financijske krize i reakcija monetarne politike u Hrvatskoj”, Istraživanja, I-25, 1-47.

32 Croatian National Bank (2009): Banks Bulletin, 9(19), https://www.hnb.hr/documents/20182/121684/ebilten-o-bankama-19.pdf/c33b15ea-9a1d-41fa-a3aa-0477664646e1 (retrieved 12.10.2015) 
Table 1: Structure of loan allocation of Croatian banks (Authors' calculations according to the data from Družić. 2001 and Croatian National Bank, 2007, 2009 and 2015)

\begin{tabular}{|c|c|c|c|}
\hline Year & Corporate loans & Household loans & Other loans \\
\hline $\mathbf{1 9 9 4}$ & $69,9 \%$ & $28,8 \%$ & $1,3 \%$ \\
\hline $\mathbf{2 0 0 6}$ & $40,0 \%$ & $39,4 \%$ & $20,6 \%$ \\
\hline $\mathbf{2 0 0 8}$ & $38,1 \%$ & $49,8 \%$ & $12,1 \%$ \\
\hline $\mathbf{2 0 1 4}$ & $34,2 \%$ & $45,4 \%$ & $20,4 \%$ \\
\hline
\end{tabular}

Source: Authors' calculations according to the data from Družić. 2001 and Croatian National Bank, 2007, 2009 and 2015

From the changing proportions of the loan allocation that favor households and government (the major part of the 'other loans' column) on account of corporate sector it can be concluded that banks have oriented their business toward household sector. Such shift ensures growth and development of banking business with the changing value sets that favor consumerism, also causing a significant increase of personal debt.

Figure 1: Loans of credit institutions in Croatia, 2003-2014, the annual change of growth

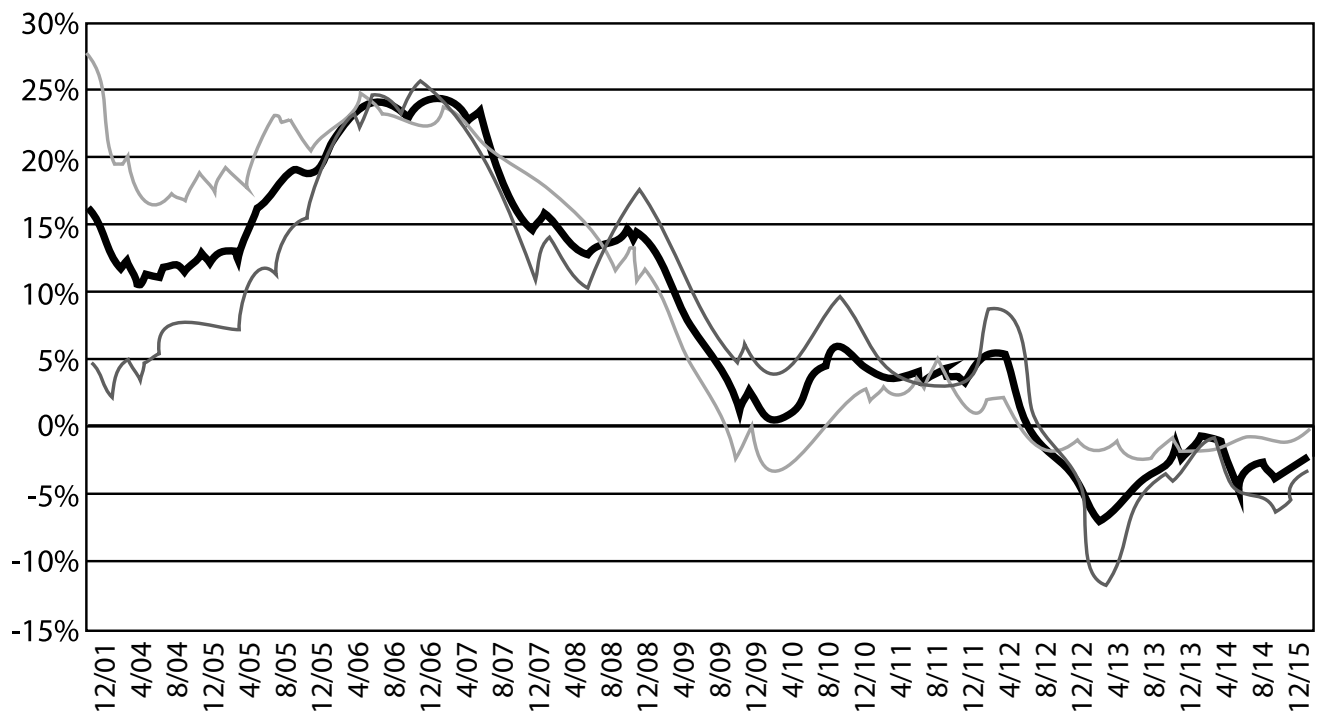

\footnotetext{
Average credit changes (In \%) Households Companies
}

Source: Authors' calculations based on the data from Croatian National Bank, 2015 
The impact of financial and economic crisis on the credit market can be seen from Chart 1 which presents the annual change of growth of retail lending (household and corporate).

The impact of crisis is obvious and the credit market has still not recovered. The corporate lending is more sensitive to business cycles than the households, which provides another reason for banks to prefer doing business with households.

In the same period the trend of bad loans growth can be detected. The data on the dynamics of bad, non-performing loans in the period form 2010-2014 is presented in Chart 2.

Figure 2: Share of non-performing loans, 2010-2015

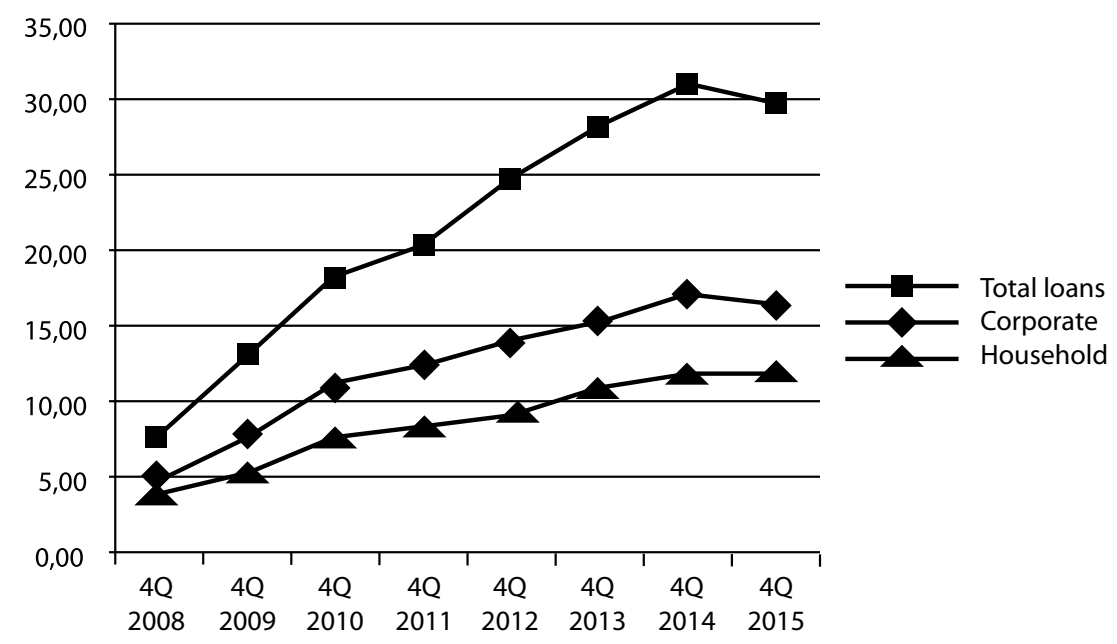

Source: Authors' calculations based on the data from Croatian National Bank, 2016

Even though the economic and financial crisis had an impact on the decrease of total debt, there was a considerable increase in the share of bad loans. In the period from 2009 to 2012 the corporate bad loans increased by about 18 percentage points and in 2014 they reached a level of over 30\%. In 2015 total and corporate bad loans decreased, whereas household bad loans still demonstrated a growing trend, reaching their peak in 2015 at the level of $12,15 \%$. Households were faced with the increase in interest rates, raising costs of living, high levels of unemployment, all deteriorating their ability to repay loans, and resulting in ever growing over-indebtedness. Total household loans amounted to 120 billion kunas at the end 2015, and bad loans account for 14,6 billion. ${ }^{33}$ The level of nonperforming loans means that almost every 8 th household loan might default.

33 Croatian National Bank (2016): Indicators of credit institution operations, Loan quality by sectors, https://www.hnb.hr/statistics/statistical-data/credit-institutions/indicators-ofcredit-institution-operations (retrieved 20.03.2016) 
Figure 3: Croatian GDP and total household credits 2000-2014

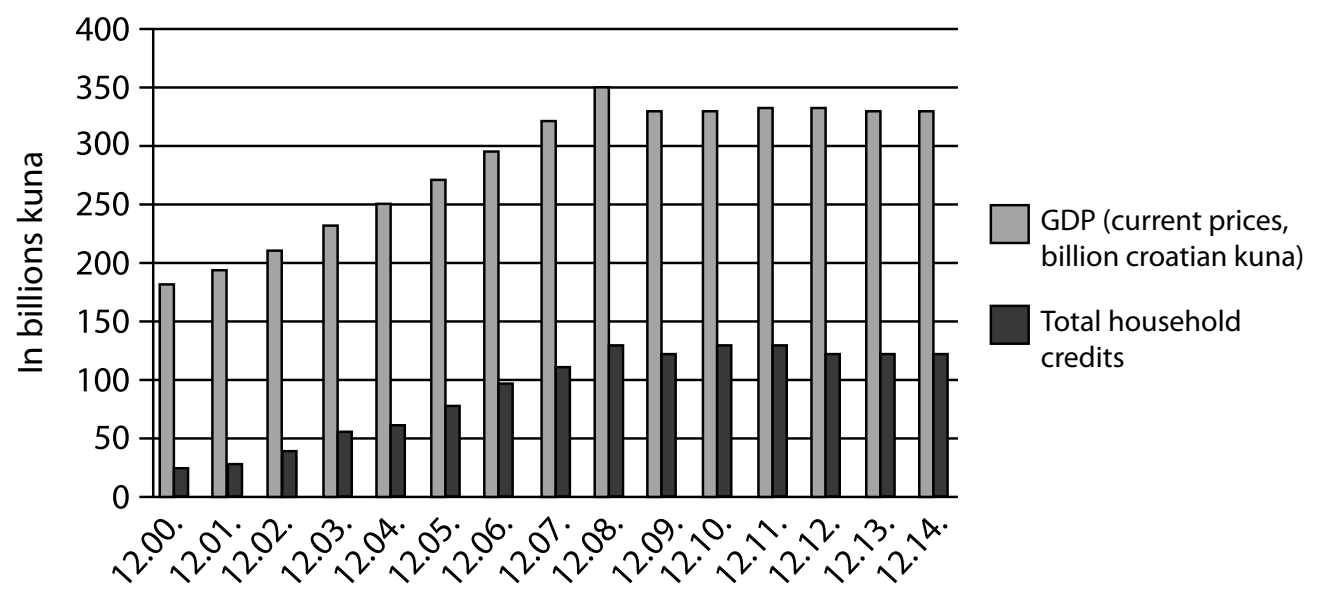

Source: Authors' calculations based on the data from Croatian Bureau of Statistics, 2014 and Croatian National Bank, 2015)

Another trend is aligned with the above stated that of a sizable increase in property foreclosures. Data shows that there were 319 foreclosed properties in Croatia in 2006, 6773 in 2013, and more than 1600 in the first two months of 2015. In the last five years 126.378 property foreclosures were initiated. ${ }^{34}$ This is also a consequence of a long period of economic crisis, and the fall of the standard of Croatian citizens coupled with over-indebtedness.

Further evidence of the above is given by the data on the frozen accounts of individuals in Croatia. At the beginning of 2015 over 313 thousand persons had a frozen transactions account, with total debt of over 31 billion kunas. 64\% of their debt is to the financial sector. ${ }^{35}$ By the end of 2015 the number of frozen account rose to over 321 thousand, and their debt rose to over 36,5 billion kunas (an increase of over 17\% in just one year). The total debt increased by $206 \%$ in the period from 2012-2015. ${ }^{36}$ Most of the individuals with frozen accounts were in that situation continuously for longer than a year.

The financial crisis and the growing trend of bad loans caused the decrease of all household loans except for non-purpose loans which steadily rose from 36,4

34 Zagrebačka banka (2016): “Aktualnosti na tržištu nekretnina u Hrvatskoj”, ZaNe Bilten 13, 4(2), 14-16, http://www.zane.hr/wps/wcm/connect/zane_web/zane/bilten (retreived 15.02.2016), 15.

35 Financial Agency (2015): Pregled blokiranih građana po vjerovnicima i ročnosti - stanje 31.1.2015, Objave 2015, http://www.fina.hr/Default.aspx?sec=1759 (retrieved 10.01.2016)

36 Financial Agency (2016): Pregled blokiranih građana po vjerovnicima i ročnosti - stanje 31.12.2015. Objave 2015, http://www.fina.hr/Default.aspx?sec=1801 (retrieved 10.01.2016) 
billion kunas in 2012 to 39,8 billion by the end of $2015 .{ }^{37}$ This presents another argument in line with the growing problem of personal indebtedness. Namely, the non-purpose loans are usually used as a means to pay short term obligations, such as current living expenses or to reprogram the old debt.

The line of reasoning that the financial crisis and household borrowing patterns are very much related is clearly seen from the following data. The level of GDP and total household loans are presented in Chart 3.

The relationship between the level of household loans from Croatian banks and the level of GDP is strong. The correlation analysis shows that total household loans ${ }^{38}$ are highly positively correlated with $\mathrm{GDP}^{39}$, with Pearson correlation coefficient of $0.96(\mathrm{p}<0.01)$ (Authors' calculations). Finally, the increase in the credit supply should lower the cost of capital and boost economic growth. Accordingly, a credit growth should represent an increase of supply of the capital and the growth of gross domestic product of the economy. At the same time, this leads to an increase in household spending and additional borrowing.

Similar trends have been documented in literature, which proves that the described tends in Croatia fit into the wider spread trends of rising personal indebtedness. Luckett's research reveals that more uncertainty leads to an increase in precautionary savings, or conversely, a decrease in debt. ${ }^{40}$ Lamdin's analysis of the US market shows that total consumer debt as a percentage of GDP had risen from 1960s to $2005 .{ }^{41}$ As early as in the 50's Galbraith and in the 70's Simon had highlighted the responsibility of advertising and other sales promotion for the rising consumption rate and falling savings rate. ${ }^{42}$ As Galbraith ${ }^{43}$ put it: 'Viewing this process as a whole, we should expect that every increase in consumption will bring a further increase - possibly a more than a proportional one - in consumer debt. Our march to higher living standards will be paced, as a matter of necessity, by an even deeper plunge into debt'.

In conclusion, the increase of lending to the households, but also to the corporate sector and the government, results in the increased indebtedness of the whole society. According to the demonstrated relationship between household 37 Croatian National Bank (2016).

38 Croatian National Bank (2010, 2015): Bulletin, various issues, https://www.hnb.hr/analyses-and-publications/regular-publications/bulletin (retrieved 20.09.2015)

39 Croatian Bureau of Statistics (2014): "Annual Gross Domestic Product, 1995- 2012 (ESA 2010)", First Release, 51(12.1.5), http://www.dzs.hr/default_e.htm (retrieved 15.10.2015)

40 Luckett, C. (2002): "Personal bankruptcies", in: T. Durkin and M. Saten (eds.) The Impact of Public Policy on Consumer Credit, 69-102, Springer, New York.

${ }_{41}$ Lamdin, J. D. (2008): "Galbraith on Advertising, Credit, and Consumption: A Retrospective and Empirical Investigation with Policy Implications”, Review of Political Economy, 20(4), 595-611.

42 Simon, J. L. (1970): Issues in the Economics of Advertising, University of Illinois Press, Urbana.

43 Galbraith, J.K. (1958): The Affluent Society, Houghton Mifflin, New York. 
lending and the Croatian GDP it can be said that the improvement in the economic situation of the country and eased credit conditions lead to the increase in personal indebtedness.

\section{Bank marketing as consumption stimulator}

Marketing involves tools and activities that have been considered more as art than science. But contemporary needs of business call on marketing discipline to be accountable and link its contributions to financial performance so it can determine the level of new value it has given to the company. ${ }^{44}$ The implications of marketing activities have been confirmed in many scientific and professional studies. The CMO Council states that marketing has an impact on accelerating drive for greater effectiveness and continuous improvement of business. ${ }^{45}$ It can reduce business costs and increase returns, increase the value to the firm and to the consumer, which makes it a cornerstone for continuous improvement. Stewart pointed out that its activities may provide a reasonable estimate of the profitability of the business. ${ }^{46}$ More specifically, the increased spending on marketing activities (advertising and promotion) in banking industry causes the profits and market share to increase significantly. ${ }^{47}$

Theoretical concepts of psychology of consumption, marketing and consumer behavior are used in explanation of the emergence of the phenomenon of consumer society and the rise of consumerism in the postwar period in the developed, western world. ${ }^{48}$ Consequently, the growth of personal debt has to be examined from the point of view that takes into consideration the impact of marketing powered by new technology. In banking (as in other businesses) this has facilitating effect on screening of consumer needs, wishes and possibilities, it adds to the speed of decision-making process and cuts cost with increased efficiency of marketing investments. Technological improvements in banking that were stimulated by deregulation and rising market competition brought about not only more efficient business to the banks, but also a chance to exploit economies of scale in consumer lending, both in terms of their geographic scope and operations scale. ${ }^{49}$ It improved possibilities of credit allocation and made it possible to establish closer communication with customers, for example through mobile messaging systems, social network

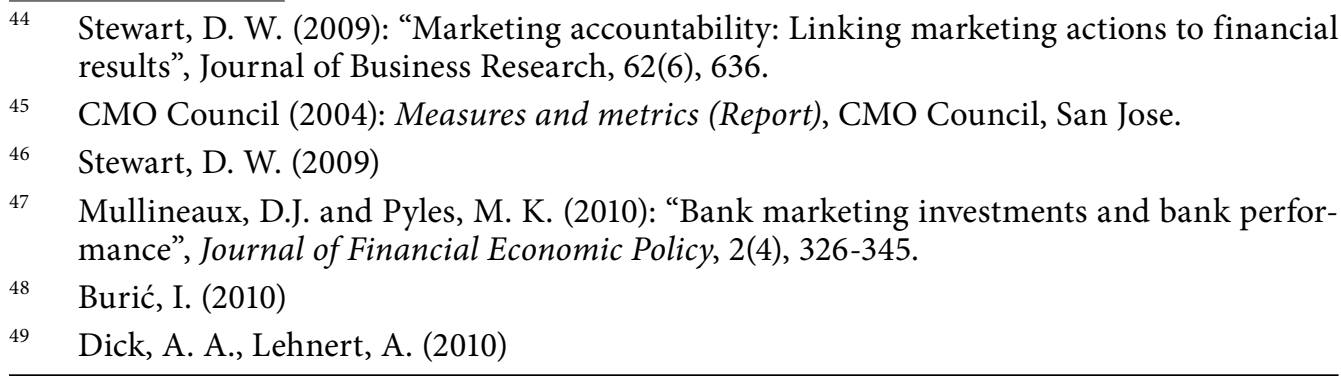


notifications, personalized e-mails and conventional letters. But on the other hand, the effect of these developments on personal indebtedness is evident and significant. Data presented by Dick and Lehnert supports the theory that the expansion of the availability of credit, following deregulation, may lead to the expansion of the supply of consumer credit and rising personal bankruptcy rates. ${ }^{50}$

The example of credit limit approval as a type of marketing tool proves its power on boosting consumer consumption and over-indebtedness. Consumers use the size of the credit limit available to them as a signal of their future earnings potential, and hence the available credit limit positively impacts the propensity to spend. ${ }^{11}$ Personalized advertising (enabled by sophisticated software solutions in banking) makes it more likely that a person would choose particular personalized special offer for further indebtedness dedicated just to him or her. The practice of telling consumers that they 'deserve' increases in their credit limits is not only non-informative, but might also mislead consumers into believing that their projected future net worth has actually increased. Marketing content can be shown as a powerful tool of future financial engagements of consumers and therefore of special interest for banks trying to add more value to their services and increase profits. By development and improvement of consumer experience, different advertisements and promotion techniques follow the innovative way of thinking and show the ideas in the content. A scientific direct mail marketing field experiment conducted in South Africa tried to determine to what extent and in what way various marketing content techniques affect demand for credit. ${ }^{52}$ The results showed that specific marketing content oriented to consumers, in this case a photo of an attractive woman, increases consumer loan demand by about as much as a $25 \%$ reduction in the interest rate. Therefore, it has been proven that effective marketing content is as powerful as the interest rate level in deciding upon getting a credit. These results show that banking advertising and promotion costs are successful tools of boosting consumption and consequently an active agent of the worsening problem of private over-indebtedness worldwide.

\section{Conclusion}

Contemporary business environment in Croatia is affected by dynamic changes in global business trends. The banks are led by the objective to achieve sustainable profitability and increase the market share. The presence of economic and financial crisis in Croatia has encouraged innovation and diversification of

\footnotetext{
50 Ibid.

51 Cheema, A. and Soman, D. (2002): “The Effect of Credit on Spending Decisions: The Role of the Credit Limit and Credibility", Marketing Science, 21(1), 32-53.

52 Bertrand, M. et. al. (2010): "What's Advertising Content Worth? Evidence from a Consumer Credit Marketing Field Experiment”, The Quarterly Journal of Economics, 125 (1), 263-306.
} 
the methods used to approach the consumers, clients of the banks. Consequently, the aim of the bank's business in the 21st century is the creation of personalized offers to customers in order to preserve long term bank-client relationship, and induce loyalty which contributes to the growth of the indebtedness of households.

The latest data shows no relaxation of the trend of rising consumerism. On the contrary, if an economy is in the phase of recovery, this encourages and motivates customers to borrow additional funds or use additional bank services. There is further evidence of the existence of democratization of credit that was spurred by the revolving credit card revolution and resulted in the extension of credit to new (and seemingly riskier, but also the most profitable) borrowers in the recent decades. ${ }^{53}$ The mechanism is quite intuitive: as lending technology improves, it makes lending to riskier types (associated with greater expected deadweight losses of default) profitable. This means that new loans are relatively more risky ones. New instruments, tools and opportunities that are offered to the consumers, such as contactless payment, revolving services, digitalized wallets or payment via mobile phone, allow consumers easier, simpler and faster (seemingly at lower costs) borrowing, regardless of socioeconomic status.

The future brings new questions and challenges to both: banking industry and regulator. The emphasis will certainly be on control of consumption and indebtedness. Even though the lender should utilize all available information to determine the future potential earnings of the consumer, the client should also do his/her part in the process: read carefully the information given by the bank, as well as participate in an interview with a consumer loan officer. However, there are no formal guidelines for banks (set by regulator) to apply in setting credit limits. The growing problem of personal debt needs also to be considered beyond the discourse of poor money management. ${ }^{54}$ Competent institutional framework should set rules and regulations that would enable the banks and the government to improve the household quality of life through sustainable levels of indebtedness. This should be done by efficient control of the operations of all financial institutions that have an impact on the household indebtedness, especially the most important ones: the banks. The social acceptability of enormous marketing budgets of banks should be reviewed and adequately regulated (downsized and/or abandoned).

The rising bankruptcy and over-indebtedness trends seem to have been broken only by the reforms of the personal bankruptcy system. ${ }^{55}$ This research also highlights the necessity of policy measures to control the seemingly indiscriminate increases in credit limits. By paying attention to existing alternatives for over-indebted consumers, such as discharge of debts and (partially) repayment,

53 Drozd, L. and Serrano-Padial, R. (2014): "Modeling the Revolving Revolution: The Role of IT Reconsidered (Working paper)”, http://finance.wharton.upenn.edu/ ldrozd/my_files/ creditcards.pdf (retrieved 05.03.2016)

54 Harper, D. J. (2003)

55 Livshits, I. (2015)

Vol. 14, № 1, 2017: 187-206 
it is necessary that the regulator should ensure stable, fair, efficient and transparent financial system (with transparent data) to protect the creditor, saver and investor who are doing business with the particular bank.

The regulator is also responsible for developing and implementing initiatives intended to educate and empower consumers to make better informed financial decisions. The financial literacy should be improved so that people can act more rationally. This extends to the behavior and rationality of the employees of the bank since no rational lender would advance a loan that will certainly not be repaid. Households should be aware of the effects that economic downturns have on the indebtedness and respond by accumulating precautionary savings, and reducing their debts. ${ }^{56}$

Responsible lending practices cover a wide array of measures that can prevent issuing and getting a credit with high chances of default and with great impact on elevation of personal indebtedness. They include consumer education, promotion of financial literacy, responsible marketing, the cost of credit regulation, pre-agreement screening or assessment of consumers. ${ }^{57}$ The focus so far has been much more on irresponsible borrowing, and it should also shift to irresponsible lending. ${ }^{58}$ It is necessary to benchmark efficiency of lending regimes and make them proactive and responsible. The most important goal is the protection of the consumers from the harm of reckless lending, avoiding over-indebtedness, including that during the financial crises. The lending practices should not be over-restrictive and should make it possible for individuals, even with low income, to indeed repay loans. This can be done through appropriate, individualistic credit assessment process and by structured repayments and loan terms so that borrowers can repay without substantial hardship. The regulator has a duty to be vigilant and monitor compliance by credit providers. Evidence shows that consumers are more protected and 'made responsible' by such regime. ${ }^{59}$

The treatment of over-indebtedness will certainly reflect the tensions between consumer protection and the promotion of consumer credit as a perceived engine of growth. Government should take on a proactive role in ensuring provision of responsible lending, introduce greater controls on credit, especially revolving and possibly even restrict marketing of banking services, especially household credit. It remains unclear to what extent such measures would affect levels of personal over-indebtedness.

56 Ibid.

57 Renke, S. (2012): An Evaluation of Debt Prevention Measures in Terms of the National Credit Act 34 of 2005, University of Pretoria, Pretoria.

58 Wilson, T. (2004): “The inadequacy of the current regulatory response to payday lending”, Australian Business Law Review, 32(3), 193-206.

59 Van Heerden, C., Renke, S. (2015) 


\section{Literature}

- Attali, J. (2009): “Kriza, a poslije?”, Meandar Media, Zagreb.

- $\quad$ Bertrand, M., Karlan, D., Mullainathan, S., Shafir, E. and Zinman J. (2010): "What's Advertising Content Worth? Evidence from a Consumer Credit Marketing Field Experiment”, The Quarterly Journal of Economics, 125 (1), 263-306.

- Bilgin, Z. and Yavas, U. (1995): "Marketing of Consumer Credit Services in a Developing Country - A Status Report", International Journal of Bank Marketing, 13(5), 311-36.

- Black, S. E. and Strahan, P.E. (2002): "Entrepreneurship and Bank Credit Availability", The Journal of Finance, 57(6), 2807-2833.

- Bokan, N., Grgurić, L., Krznar, I., Lang, M. (2010): “Utjecaj financijske krize i reakcija monetarne politike u Hrvatskoj”, Istraživanja, I-25, 1-47.

- Burić, I. (2010): Nacija zaduženih, Zagreb: Naklada Jesenski i Turk, Hrvatsko sociološko društvo.

- Cameron, S. and Golby, D. (1990): "Correlates of Over-Commitment in a Sample of Crisis Debtors", in: S.E.G. Lea, P. Webley and B.M. Young (eds.), Applied economic psychology in the 1990s, 467-475, Exeter: Washington Singer Press.

- Cheema, A. and Soman, D. (2002): "The Effect of Credit on Spending Decisions: The Role of the Credit Limit and Credibility", Marketing Science, 21(1), 32-53.

- CMO Council (2004): "Measures and metrics (Report)", CMO Council, San Jose.

- Consumer Financial Protection Bureau [CFPB] (2013): "Navigating the Market: A Comparison of Spending on Financial Education and Financial Marketing", Consumer Financial Protection Bureau, Washington,

- http://files.consumerfinance.gov/f/201311_cfpb_navigating-the-marketfinal.pdf (retrieved 10.03.2016)

- Croatian Bureau of Statistics (2014): "Annual Gross Domestic Product, 19952012 (ESA 2010)”, First Release, 51(12.1.5), http://www.dzs.hr/default_e.htm (retrieved 15.10.2015)

- Croatian National Bank (2007, 2009, 2015): “Agregirano statističko izvješće banaka", various editions, http://nbhnetra.hnb.hr/statistika/agregiranoizvjesce_prije-revizije/h-agrerirano-izvjesce_prije-revizije.htm (retrieved 10.04.2016)

- Croatian National Bank (2009): “Banks Bulletin”, 9(19), https://www.hnb.hr/ documents/20182/121684/ebilten-o-bankama-19.pdf/c33b15ea-9a1d-41faa3aa-0477664646el (retrieved 12.10.2015)

- Croatian National Bank (2010, 2015): “Bulletin”, various issues, https://www. hnb.hr/analyses-and-publications/regular-publications/bulletin (retrieved 20.09.2015) 
- Croatian National Bank (2016): "Indicators of credit institution operations, Loan quality by sectors", https://www.hnb.hr/statistics/statistical-data/ credit-institutions/indicators-of-credit-institution-operations (retrieved 20.03.2016)

- Dick, A. A. and Lehnert, A. (2010): "Personal Bankruptcy and Credit Market Competition", The Journal of Finance, 65(2), 655-686.

- Drozd, L. and Serrano-Padial, R. (2014): "Modeling the Revolving Revolution: The Role of IT Reconsidered (Working paper)", http://finance.wharton. upenn.edu/ ldrozd/my_files/creditcards.pdf (retrieved 05.03.2016)

- Družić, G. (2001): "Banking System”, Ekonomski pregled/Economic Review, 52(3-4), 293-313.

- European Commission (2008): “Towards a Common Operational European Definition of Over-Indebtedness", DG Employment, Social Affairs and Equal Opportunities, Brussels.

- Financial Agency (2015): "Pregled blokiranih građana po vjerovnicima i ročnosti - stanje 31.1.2015”, Objave 2015, http://www.fina.hr/Default. aspx?sec=1759 (retrieved 10.01.2016)

- Financial Agency (2016): "Pregled blokiranih građana po vjerovnicima i ročnosti - stanje 31.12.2015”. Objave 2015, http://www.fina.hr/Default. aspx?sec=1801 (retrieved 10.01.2016)

- Galbraith, J.K. (1958): “The Affluent Society”, Houghton Mifflin, New York.

- Gross, D.B. and Souleles, N.S. (2002): "An Empirical Analysis of Personal Bankruptcy and Delinquency", Review of Financial Studies, 15(1), 319-347.

- Harper, D. J. (2003): "Poverty and Discourse", in: S.C. Carr and T.S. Sloan (Eds.) Poverty and Psychology: From Global Perspective to Local Practice, (pp. 185-203), Springer, New York.

- Janković, B. (2009): "Bank marketing in times of the global economic crisis - risk and/or chance?”, Bankarstvo, 39(9-10), 52-69, http://www.ubs-asb. com/Portals/0/Casopis/2009/9_10/B09-10-2009-Jankovic.pdf (retrieved 25.09.2015)

- Kahneman, D. and Tversky, A. (2000): “Choices, Values and Frames”, Cambridge University Press, Cambridge.

- Lamdin, J. D. (2008): "Galbraith on Advertising, Credit, and Consumption: A Retrospective and Empirical Investigation with Policy Implications", Review of Political Economy, 20(4), 595-611.

- Leigh-Pemberton, R. (1989): "Personal credit problems", Bank of England Quarterly Bulletin, 29(May), 243-245.

- Livshits, I. (2015): "Recent Developments in Consumer Credit and Default Literature", Journal of Economic Surveys, 29(4), 594-613.

- Lunt, P. (1992): "What boosts card usage?", ABA Banking Journal, 84(30), 82-85. 
- Luckett, C. (2002): “Personal bankruptcies", in: T. Durkin and M. Saten (eds.) The Impact of Public Policy on Consumer Credit, 69-102, Springer, New York.

- Ludvigson, S. (1999): "Consumption and Credit: A Model of Time-Varying Liquidity Constraints", The Review of Economics and Statistics, 81(3), 434-447.

- Modigliani, F., Brumberg, R. (1954): "Utility Analysis and the Consumption Function: An Interpretation of Cross-section Data", in: K. K. Kurihara (ed.) Post Keynesian Economics, (pp. 388-436), Rutgers University Press, New Brunswick.

- Mullineaux, D.J. and Pyles, M. K. (2010): “Bank marketing investments and bank performance", Journal of Financial Economic Policy, 2(4), 326-345.

- Punch, L. (1992): “The latest anti-attrition tool: More credit”, Credit Card Management, 5(5), 48-51.

- Ramsay, I. (2012): “A Tale of Two Debtors: Responding to the Shock of OverIndebtedness in France and England - A Story from the Trente Piteuses", Modern Law Review, 75(2), 212-248.

- Renke, S. (2012): "An Evaluation of Debt Prevention Measures in Terms of the National Credit Act 34 of 2005", University of Pretoria, Pretoria.

- Simon, J. L. (1970): "Issues in the Economics of Advertising", University of Illinois Press, Urbana.

- Stewart, D. W. (2009): "Marketing accountability: Linking marketing actions to financial results", Journal of Business Research, 62(6), 636-643.

- Turan, Ö., Ugur, D. i Barlas, Y. (2013): "Dynamics of Consumerism and Credit Card Debt under the Influence of Advertising", in: 31st International Conference of the System Dynamics Society 2013 Proceedings, 3852-3867.

- $\quad$ http://www.systemdynamics.org/conferences/2013/proceed/papers/P1301. pdf (retreived 10.11.2015)

- Van Heerden, C. and Renke, S. (2015): "Perspectives on the South African Responsible Lending Regime and the Duty to Conduct Pre-agreement Assessment as a Responsible Lending Practice", International Insolvency Review, 24(2), 67-95.

- Westerman, G., Tannou, M., Bonnet, D., Ferraris, P. and McAfee, A. (2012): "The Digital Advantage: How digital leaders outperform their peers in every industry (Working paper)", MA: MIT Sloan Management, Cambridge.

- Wilson, T. (2004): "The inadequacy of the current regulatory response to payday lending", Australian Business Law Review, 32(3), 193-206.

- Walker, C. (2012): "Personal Debt, Cognitive Delinquency and Techniques of Governmentality: Neoliberal Constructions of Financial Inadequacy in the UK", Journal of Community \& Applied Social Psychology, 22(6), 533-538.

- Zagrebačka banka (2016): "Aktualnosti na tržištu nekretnina u Hrvatskoj", ZaNe Bilten 13, 4(2), 14-16, http://www.zane.hr/wps/wcm/connect/zane_ web/zane/bilten (retreived 15.02.2016) 


\section{IVAN FiLIPOVić}

Primorsko-goranska županija, Hrvatska

Dr Dunja Š́Kalamera-Alilović, vaNREDNi PROFESOR

Ekonomski fakultet, Sveučilište u Rijeci, Hrvatska

Dr ANa ŠTAMBuK, DOCENT

Ekonomski fakultet, Sveučilište u Rijeci, Hrvatska

\section{POSLOVANJE BANAKA I OSOBNA ZADUŽENOST U HRVATSKOJ}

Društveni fenomen osobne prezaduženosti nastao je u posljednjih trideset godina. Trend prekomjernog zaduživanja kućanstava $i$ dalje uzima sve većeg maha, što stavlja problem osobne prezaduženosti u fokus interesa regulatora, istraživačke zajednice i javnosti općenito. U Hrvatskoj se neprestano povećava broj zaduženih osoba kao i onih čiji su računi u bankama blokirani. Jedan od temeljnih uzroka nastanka prezaduženosti jest olakšavanje kućanstvima pristup kreditu, a uz nepromijenjene razine dohotka. Istraživanja potvrđuju postojanje procesa „demokratizacije kredita“ koji je potaknut deregulacijom u financijskom sektoru. Rijetka su istraživanja koja se bave ulogom banaka i njihovih poslovnih politika u povećavanju razine zaduženosti kućanstava. Marketing banaka, posebice oglašavanje i promocija, predstavljaju način komuniciranja s klijentima, a postoje dokazi da atraktivan sadržaj marketinške poruke utječe jednako značajno na odluku o zaduživanju kao i smanjenje kamatne stope. Navedeno predstavlja motiv za daljnje istraživanje moguće povezanosti između marketinških napora banaka $i$ razine osobne zaduženosti.

Ovaj rad argumentira proaktivnu ulogu bankarskog sektora, motiviranog profitom, uz nedostatak adekvatne kvalitete i razine regulacije, na povećanje broja prezaduženih osoba u Hrvatskoj. Dodatno se uzima u obzir i utjecaj ekonomskih kolebanja na proučavani odnos između bankarskih aktivnosti i zaduženosti stanovništva. Analiza se temelji na podacima iz agregiranih financijskih izvješća banaka i odabranim makroekonomskim pokazateljima. Cilj istraživanja je opisati i objasniti kako banke utječu na ponašanje potrošača, i posljedično potiču rast osobne zaduženosti u Hrvatskoj.

Ključne riječi: poslovanje banaka, ponašanje potrošača, Hrvatska, osobna prezaduženost 